\title{
TPM3/ALK Fusion Gene
}

National Cancer Institute

\section{Source}

National Cancer Institute. TPM3/ALK Fusion Gene. NCI Thesaurus. Code C101083.

A fusion gene that results from a chromosomal translocation $\mathrm{t}(1 ; 2)(\mathrm{q} 25 ; \mathrm{p} 23)$ which fuses most of the coding sequence of the TPM3 gene to the last 10 exons of the ALK gene.

This rearrangement is associated with anaplastic large cell lymphoma and inflammatory myofibroblastic tumor. 